\title{
TLR signals modify the expression of scavenger receptors
}

\author{
C Zamora $^{1 *}$, E Cantó $^{1}$, J C Nieto ${ }^{1}$, C Juarez ${ }^{2}$, S Vidal $^{1}$ \\ From 5th European Workshop on Immune-Mediated Inflammatory Diseases \\ Sitges-Barcelona, Spain. 1-3 December 2010
}

\section{Introduction}

Toll like receptors (TLRs) and scavenger receptors are expressed on the surface of monocytes in order to participate in relevant innate immune functions. It has been established that TLRs can discriminate molecular structures normally absent in the healthy host, whereas CD36 is a class B scavenger receptor that can coordinate responses to TLR2:TLR6 agonists. Although recent studies have focused on CD36-TLR cooperation in mediating phagocytosis, it is not know whether TLRs can regulate the expression of scavenger receptors.

\section{Aim}

To understand how TLR signals can interact with scavenger receptors, we analyzed the expression of CD36 on monocytes after the stimulation with TLR4 (LPS) and TLR2 (Pam3CSK4 and FSL1) ligands.

\section{Methods}

Human peripheral blood mononuclear cells (PBMCs) from healthy donors were incubated with Pam3CSK4, (TLR2:TLR1 ligand) FSL1 (TLR2:TLR6 ligand) and ultrapure LPS (TLR4 ligand). After 24, 48 and 72 hours of culture, CD36 expression was analyzed by flow cytometry and cytokine production in the supernatants was determined by ELISA.

\section{Results}

After culturing with each TLR ligand, CD36 expression was downregulated on CD14+ monocytes, being LPS the ligand with the strongest effect. The kinetics analysis revealed that $48 \mathrm{~h}$ was the peak of downregulation, with the recovery of CD36 expression at 72h in Pam3CSK4 and FSL1 cultures. Since the binding of TLR ligands induced cytokine production and secretion, we analyzed whether these cytokines

1Dept. Immunologia, Institut Rec. Hospital S. Creu i S. Pau, Barcelona, Spain Full list of author information is available at the end of the article were responsible for the observed downregulation. TNFalpha and IFNgamma (at lesser extent) but not IL-10 were able to downregulate CD36 expression. Blocking specifically the TNF effect after TLR binding with neutralizing antibodies, CD36 downregulation was partially abrogated. While after TLR2 or TLR4 binding, CD36 was downregulated by internalization, other scavenger receptors or molecules involved in the TLR ligand recognition were not modulated.

\section{Conclusion}

Since CD36 is required for TLR responses, the TLRinduced downregulation of CD36 could operate as a regulator of the innate immune response through TLRs.

\section{Author details}

${ }^{1}$ Dept. Immunologia, Institut Rec. Hospital S. Creu i S. Pau, Barcelona, Spain. ${ }^{2}$ Dept. Immunologia, Hospital S. Creu i S. Pau, Barcelona, Spain.

Published: 25 November 2010

doi:10.1186/1479-5876-8-S1-P4

Cite this article as: Zamora et al: TLR signals modify the expression of scavenger receptors. Journal of Translational Medicine 2010 8(Suppl 1):P4.

Submit your next manuscript to BioMed Central and take full advantage of:

- Convenient online submission

- Thorough peer review

- No space constraints or color figure charges

- Immediate publication on acceptance

- Inclusion in PubMed, CAS, Scopus and Google Scholar

- Research which is freely available for redistribution 